Benito Arruñada

\title{
Price regulation of plastic money: \\ A critical assessment of Spanish rules
}

Published in European Business Organization Law Review, 2005, 6(4), 625-650.

Universitat Pompeu Fabra

Department of Economics and Business

Barcelona, October 21, 2005 


\title{
Price regulation of plastic money: A critical assessment of Spanish rules
}

\begin{abstract}
Recent decisions by the Spanish national competition authority (TDC) mandate payment systems to include only two costs when setting their domestic multilateral interchange fees (MIF): a fixed processing cost and a variable cost for the risk of fraud. This artificial lowering of MIFs will not lower consumer prices, because of uncompetitive retailing; but it will however lead to higher cardholders' fees and, likely, new prices for point of sale terminals, delaying the development of the immature Spanish card market. Also, to the extent that increased cardholders' fees do not offset the fall in MIFs revenue, the task of issuing new cards will be underpaid relatively to the task of acquiring new merchants, causing an imbalance between the two sides of the networks. Moreover, the pricing scheme arising from the decisions will cause unbundling and underprovision of those services whose costs are excluded. Indeed, the payment guarantee and the free funding period will tend to be removed from the package of services currently provided, to be either provided by third parties, by issuers for a separate fee, or not provided at all, especially to smaller and medium-sized merchants. Transaction services will also suffer the consequences that the TDC precludes pricing them in variable terms.
\end{abstract}

Key words: credit cards, payment systems, regulation, interchange fees

JEL codes: K21, K23, L14, L41

\footnotetext{
* Department of Economics and Business, Universitat Pompeu Fabra, Trias Fargas, 25-27, 08005-Barcelona (Spain). E-mail: benito.arrunada@upf.edu. Website: http://www.econ.upf.es/ arrunada. This work has received financial support from the MCYT, an agency of the Spanish Government, through grant SEC2002-04471-C0202, and the European Commission, through the Integrated Project "Reflexive Governance in the Public Interest”. Comments on earlier versions received from Javier González-Díez, Rainer Kulms and Celestino S. Viñuela are gratefully acknowledged. The author alone is responsible for the opinions expressed in this paper or for any errors it may contain.
} 


\section{Introduction and summary}

According to recent decisions of the Spanish national competition authority, the Tribunal de Defensa de la Competencia (TDC), on Cases 4B, Servired and Euro 6000, which deal with the interchange fees determined by the Spanish payment networks for domestic card transactions made within each of the systems, ${ }^{1}$ four-party payment systems can only include two costs when setting domestic multilateral interchange fees (MIFs): a fixed cost for processing each transaction, whatever its value; and a variable ad valorem cost for the risk of fraud.

The TDC therefore rejects the possibility of including the cost of the payment guarantee beyond fraud protection, the interest for the free funding period, as well as the possibility that processing costs may vary according to the transaction value. The TDC in fact sets the ceiling for MIFs not at cost but well below the cost of the services in question. ${ }^{2}$ Furthermore, the TDC introduces additional constraints in MIFs, precluding for example differential prices for different sectors.

This paper will examine what consequences can be expected from this regulation in the context of the Spanish market. ${ }^{3}$

The TDC supports its decision in arguments used by the European Commission in its 2002 Visa International decision, ${ }^{4}$ in which the Commission decided that the setting of MIFs by Visa in cross-border payments restricted competition under Article 81(1) EC but, considering that the MIFs, as amended by Visa, satisfied the four conditions listed in Article 81(3) EC, the Commission granted Visa an individual exemption subject to several requirements, including disclosure of MIFs to affiliated merchants and setting MIFs at a level objectively justified by costs. The Commission also considered that for this setting of MIFs three cost categories could legitimately be included: the cost of processing transactions, the cost of providing the "payment guarantee" and the cost of the "free-funding" period.

\footnotetext{
1 TDC Decisions of April 11, 2005, No. A 314/02, Tasas Intercambio SISTEMA 4B; A 318/02, Tasas Intercambio SERVIRED; and No. A 287/00 Sistema Euro 6000.

2 Using as reference the cost estimations of Visa and MasterCard in their cross-border card transactions within the European region, it can be concluded that the TDC excludes much of the total costs: The cost of the payment guarantee is estimated at $50 \%$ of total costs by both Visa and MasterCard, and the TDC would allow to include only those related to fraud. The cost of free funding period, which is fully excluded by the TDC, amounts to $26 \%$ of total costs in Visa and 25\% in MasterCard. Finally, the processing cost, whose inclusion is allowed by the TDC as a flat fee, is estimated at $24 \%$ of total costs by Visa and $25 \%$ by MasterCard in their cross-border POS transactions within the European region (percentages and more detail available at http://www.visaeu.com/acceptingvisa/interchange. html and http://www.mastercardInternationalcom/corporate/mif_information.html, accessed September 15, 2005).

3 In relation to interchange fees see, among others, David S. Evans and Richard Schmalensee, Paying with Plastic, $2^{\text {nd }}$ ed., Cambridge, MA, MIT Press, 2005; and the papers presented at two recent conferences, on “Interchange Fees in Credit and Debit Card Industries: What Role for Public Authorities?” (Federal Reserve Bank of Kansas City, Santa Fe, New Mexico, May 4-6, 2005, http://www.kc.frb.org, accessed September 15, 2005), and “Antitrust Activity in Card-Based Payment Systems: Causes and Consequences” (Federal Reserve Bank of New York, New York, September 15-16, 2005, http://www.newyorkfed.org/research/conference/2005/antitrust_activity.html, accessed September 15, 2005).

4 See Commission Decision as COMP.29.373, VISA International, OJ L 318, 22.11.2002, pp. 17-36.
} 
However, the paper will show that the TDC interprets this Visa International decision too narrowly and therefore excludes certain costs which were accepted by the European Commission as providing value to merchants and appropriately covered by MIF.

After this Introduction, the second section argues that artificially lowering interchange fees will not necessarily lead to lower consumer prices because retailing in Spain is uncompetitive. As a consequence, the new rules will primarily favor large retailers, who are in fact competitors of conventional payment systems. Lower MIFs will, however, lead to higher cardholders' fees and possibly higher prices for point of sale (POS) terminals, as banks seek to recover lost interchange revenue, which will delay the development of the immature Spanish card market. In addition, to the extent that additional revenue from cardholders' fees does not offset the fall in MIFs revenue, card issuing activities will be underpaid. This underpayment will significantly damage smaller issuers, who are disadvantaged by comparison with the larger issuers, who are best able to withstand losing revenue from one side of their business, as they are more likely to have the scale and diversity of revenue streams which are not available to the smaller issuers. As a consequence, the largest issuers will become more powerful. This may trigger undesirable transformations in the networks, such as break ups of the networks themselves, in order to rebalance the issuing and acquiring sides of the market.

The pricing scheme arising from the TDC decisions will likely cause significant unbundling and underprovision of those services the costs of which those decisions prohibit from being included in MIFs, in contravention to the reasoning contained in the Visa International decision. Indeed, services associated with the payment guarantee and the free funding period will tend to be removed from the package of services currently provided by the card issuers as part of the network offering, to be either provided by third parties, by issuers for a separate fee, or not provided at all, especially to smaller and medium-sized merchants. Transaction services will also suffer the consequences of the exclusion by the TDC of the possibility of pricing them in variable terms.

The third section focuses on the consequences of allowing issuers to receive compensation via the MIF only for the fraud component of the payment guarantee and not for other components. Issuers would not be able to charge for the credit risk guarantee and would probably stop guaranteeing payments. As a result, merchants would lose sales because there are not effective substitutes for such guarantee and merchants would therefore sell less to unknown cardholders.

Moreover, the payment guarantee is particularly costly and useful in Spain, due to the inefficiency and cost of recovering unpaid debts through Spanish courts and the significant demand existing for consumer credit. Furthermore, there are no viable substitutes in the market for the payment guarantee provided by banks and none are likely to develop, even if one were to assume that third party providers were able to gain access to lenders' databases by purchasing that information. Thus, the very same two arguments which led the Commission to accept that the cost of the payment guarantee should be included in the calculation of an interchange for cross-border transactions - that is, merchants' benefits and lack of substitutes - are present in Spanish domestic transactions. However, the TDC decisions have excluded them.

These two conditions contained in the Visa International decision are equally present with respect to the free funding period, which has been also excluded from the categories of costs accepted by the TDC. As the fourth section of this paper notes, free funding and other cash management services provided by credit card systems are especially valuable for Spanish consumers and firms, because they are not particularly methodic about cash management, as 
shown by national surveys and cross-country data, which demonstrate poor personal financial management as well as the prevalence of longer payment periods and payment delays in Spain than in other European countries. Moreover, cardholders paying with cards encounter similar difficulties in checking their bank accounts to ensure that they have sufficient funds not only in cross-border transactions, but also when conducting domestic transactions. For these reasons, it seems clear that domestic free funding benefits merchants.

Finally, section five criticizes how the TDC treats processing costs. When excluding some processing costs which in its view do not "fundamentally" benefit merchants, the TDC focuses on tangible benefits, thereby overlooking positive externalities produced by the use of cards. Similarly, the TDC ignores that some processing costs effectively vary depending on the amount and the industry sector in which the card transaction is carried out. Instead, it imposes uniform processing costs for all economic sectors. This approach will lead to inefficient and ineffective allocation of processing costs among transactions and industries which generate widely different costs.

\section{Consequences of artificially lowering MIFs in Spain}

\subsection{Lower rates will not necessarily lead to lower consumer prices in view of the uncompetitive retailing}

Regulation of MIFs is often based on two assumptions: first, it assumes that, if issuing banks charge lower MIFs to acquiring banks, the latter will also charge lower discount fees to merchants; and second, it assumes that merchants will pass through the lower discount fees to consumers as lower final prices.

This second assumption is unfounded, because, as the Visa International decision correctly points out, this two-step sequence fails when retailers are not in a competitive market. 5 Unfortunately, competition is very limited in Spanish retailing, as it has been repeatedly criticized by the IMF, the OECD and the TDC itself. ${ }^{6}$ Artificially lowered MIFs will therefore not lead to lower consumers' prices but they will only increase merchants' margins. This was expressly assumed in a recent parliamentary motion that flatly asserted that its goal was to "improve the margins of retailers and service providers."7

\footnotetext{
5 The decision conditions potential reductions in prices to strong competition in retailing: "In cases where there is strong price competition between merchants, the fall in merchants' costs [due to possibly lower discount fees] could lead to reduced prices for all consumers, including those who pay by Visa card” (para. 94).

6 International Monetary Fund, Report on Spain, Washington, January 2005; Organization for Economic Cooperation and Development, Economic Survey of Spain, Paris, 2005; and TDC, Informe sobre las condiciones de competencia en el sector de la distribución comercial, Madrid, 2003. The Spanish retailing market has become increasingly uncompetitive since 1985, due to the increased barriers to entry (redundant licensing) and the restrictive regulation of opening hours and sales existing in Spain, together with a preferential taxation.

7 Grupo Parlamentario Catalán [Convergència i Unió], “relativa al cumplimiento de las resoluciones del Tribunal de Defensa de la Competencia en materia de fijación de tasas de intercambio aplicadas sobre los pagos efectuados mediante tarjetas de crédito o débito,” April 28, Boletín Oficial de las Cortes, 161/000900, Serie D, no. 199, May 10, 2005, p. 16.
} 


\subsection{Large retailers are likely to benefit the most}

Both large and small retailers will benefit from lower MIFs, because many of them enjoy local monopoly power. ${ }^{8}$ However, large retailers are likely to benefit the most, to the extent that their business model is based on acting as financial intermediaries and increasing customers' switching costs. Large retailers are not passive distribution "channels", but vertically integrated structures, and their huge market power allows them to put pressure on suppliers and challenge the most profitable portions of their businesses. ${ }^{9}$ Card payment systems are just one of these suppliers, and as such, they are pressured and subject to competition from progressively more integrated large retailers:

Large retailers have developed their own payment systems, which come in two forms:

Firstly, by means of store cards, which in Spain enjoy a market share that almost doubles the EU average (10.03\% of total value of card transactions by comparison to $5.73 \%$ in the $\mathrm{EU})^{10}$ (see Table 1) and provide services similar to credit cards, with implicit negative fees created by free funding, perks (free parking, insurance), free financing and loyalty schemes, in addition to charging no annual fees. ${ }^{11}$

Secondly, large retailers are also main issuers of credit cards, which are then mostly used in their stores. For instance, Carrefour-the second largest retailer in the world-is currently one of the most aggressive issuers of Visa in Spain and, contrary to most Spanish issuers, it continues to offer a free Visa card to its customers. ${ }^{12}$ As retailers simultaneously act as merchants, acquirers and issuers, they become a sort of two-party payment systems, given that they have the cardholder as their only counterparty. Thus, they are increasingly effective competitors of the other payment systems.

Furthermore, large retailers develop this strategy from their very strong position as financial intermediaries, given that they control the vast funding gap provided by the difference between their long periods of payment to suppliers and their almost instantaneous collection of funds from clients.

Considering this integrating strategy of large retailers, who were the most active complainants during the TDC investigation leading to the three contested decisions, it is likely that they will benefit from the damage caused by the TDC decisions to conventional banks.

The situation is even worse from the perspective of consumers' protection, because large retailers are increasingly developing loyalty schemes that reduce competition in retailing, while the loyalty schemes of credit cards are neutral across retailers. Loyalty schemes offered by retailers differ from those offered by credit cards, because they increase the cost of switching between retailers, thereby building up their market power. The opposite happens

\footnotetext{
8 Local monopoly power has been stressed as a main feature of Spanish distribution by the former President of the TDC. See: Amadeo Petitbò, “Gallofas comerciales,” La Vanguardia, August 15, 2005.

9 See Benito Arruñada, “The Quasi-Judicial Role of Large Retailers: An Efficiency Hypothesis of their Relation with Suppliers," Revue d'Economie Industrielle, no. 92, $2^{\text {nd }}$ and $3^{\text {rd }}$ trimesters, 2000, pp. 277-296.

10 According to the data included in Commission Decision as COMP.29.373, VISA International, OJ L 293, 11.10.2001, pp. 39-41.

11 Bank of Spain, “Capítulo del Bluebook sobre España,” Madrid, 2001, p. 12 (http://www.bde.es/sispago/blueboo.pdf, accessed September 15, 2005).

12 See https://www.pass.carrefour.es (accessed September 15, 2005).
} 
with many credit card loyalty schemes because consumers obtain the bonus associated to the use of the card, regardless of the store in which they purchase.

\subsection{Lower MIFs would lead to higher card issuance and maintenance fees and possibly higher prices for POS terminals}

The MIF below cost that results from the TDC decisions would produce similar damage to the absence of a MIF, whose consequences have been pointed out by the Visa International decision (para. 102): either issuers absorb costs and recover them by charging higher fees for unrelated services or issuers charge increased annual fees or transaction-related fees to cardholders, or both. The latter possibility might destabilize the system and set a downward spiral in its use as consumers would pay fees which include the cost of services provided to merchants.

In the Spanish case, higher cardholders' fees are the most likely result of the TDC decisions, because these decisions apply to domestic transactions, which represent the vast majority of transactions in Spain instead of applying only to international transactions, as in the Visa International case decided by the Commission. For instance, while the Visa International decision affected $10 \%$ of total transaction volume, the TDC decisions affect $96 \%$ of all Visa transactions. ${ }^{13}$ Therefore, cross-subsidization between both types of transaction, domestic and international, or even from other services, is hardly possible.

Increases in the annual fees charged to cardholders should also be expected, in view of the experience in recent years, which saw some growth in annual in fees as a response to increase pressure to reduce MIFs. ${ }^{14}$ Moreover, charges to cardholders for each transaction, or depending on the transaction value, are also possible.

Another likely effect would also be the reduction or disappearance of benefits currently provided as part of the interchange fee (that is, among others, free funding and insurance) and through loyalty bonuses and reward schemes.

As a result thereof, card usage will be reduced. Marginal users will stop using cards altogether and others will switch to those cards with lower costs and services. Transaction fees will also move users to other forms of payment, some of which are heavily subsidized and cause negative externalities (mainly cash, whose production is subsidized by the government and whose use causes important negative externalities by favoring crime against merchants and even facilitating tax avoidance). ${ }^{15}$

The introduction of issuance fees is also likely. Up to now, most cards have been issued for free and some banks even pay consumers to sign up for cards, hoping to recover the 150250 euros invested in issuing each card later, ${ }^{16}$ much as phone companies give away cell

\footnotetext{
13 These are the percentages for Visa in Spain, according to Servired (TDC Decision of April 11, 2005, A 318/2002, Tasas Intercambio SERVIRED, p. 11.)

14 The main changes in this regard as well as their origins are summarized the end of section 2.4.

15 What might well be the first empirical evaluation of costs and benefits of alternative payment systems concludes that "when all key parties to a transaction are considered and benefits are added, cash and checks are more costly than many earlier studies suggest” (Daniel D. Garcia Swartz, Robert W. Hahn and Anne LayneFarrar, "The Economics of a Cashless Society: An Analysis of the Costs and Benefits of Payment Instruments," AEI-Brookings Joint Center for Regulatory Studies, Related Publication 04-24, September 2004 (http://www.aei-brookings.org/publications/abstract.php?pid=842, accessed September 15, 2005).

16 Estimate based on the experience of a high quality issuer.
} 
phones. With no hope of recovery, issuance fees will appear, new users will not be rewarded for overcoming their learning costs, and plastic money will be introduced more slowly into new segments of the populations.

Direct consequences for merchants are less certain. To the extent that the acquiring business continues to be profitable, the policy of making POS terminals available to merchants for free would be sustained or even increased. However, to the extent that pricing and contracting in the whole network would be revised, terminals would likely be priced separately (with an installation fee plus a monthly rental with fixed and variable elements). In conclusion, it is likely that merchants will end up paying more than in the current situation but offering poorer service to customers.

In sum, pricing at (or, following the TDC rules, below) measurable, tangible, costs implies ignoring the positive externalities generated by credit cards. As a consequence, both the use of cards and the availability of terminals would be dictated by individual calculation of costs and benefits, leading to suboptimal utilization and supply at the social level.

\subsection{Worst consequences in Spain due to the immaturity of the payment card market}

These consequences are aggravated by the immaturity of the Spanish market (see Table 2), which has lead the Spanish central bank to characterize Spain as "one of the EU countries worst placed with respect to the number and average value of transactions with payment cards”. ${ }^{17}$ Key elements of this immaturity are the heavy reliance in cash and the low utilization of electronic means of payment. The average Spaniard holds 30\% more cash than the European average and cash holdings per unit of GDP are 82\% greater in Spain than in the EU (see Table 2). Furthermore, although Spain has a higher number of terminals and cards per inhabitant than other EU countries (the only exception being cards with an e-money function), their use in Spain lags substantially behind EU averages. Overall, Spanish utilization rates of terminals are below half the EU average in terms of transactions and about one third in terms of value. The utilization of cards is similarly low. ${ }^{18}$ The argument that the use of cards is above the optimal level is therefore not applicable to Spain.

In particular, the Spanish payment system is underdeveloped and underutilized due to traditional consumer habits. Given these habits and the low utilization rates, prices should be set to motivate greater utilization, and this can only be achieved by introducing incentives at the cardholder side, with no issuance fees, low annual card fees, free funding period and

\footnotetext{
17 Bank of Spain, “Evolución en España de las tarjetas como medio de pago (1996-2004),” Estabilidad financiera, no. 8, May, 2005, p. 61 (http://www.bde.es/informes/be/estfin/numero8/estfin0802.pdf, accessed September 15, 2005).

18 According to a recent report by the European Central Bank (Payment and Securities Settlement Systems in the European Union: Addendum Incorporating 2003 Figures, Frankfurt am Main, Germany, August, 2005, http://www.bde.es/sispago/bbestade.pdf, accessed September 15, 2005), the number of transactions with credit cards per POS terminal is only $50.65 \%$ of the EU average and, given that the average amount per transaction in Spain is also smaller, each terminal processes a total value which is only $37.34 \%$ of the EU average. Utilization rates are even lower for ATM withdrawals and, in particular, for the use of debit cards in POS terminals. Spaniards also use their cards less than the average European: utilization is $65.95 \%$ for cards with a cash function, $24.89 \%$ for debit cards and $92.42 \%$ for credit cards. Average values per transaction are also lower, with amounts which are only 79.51, 72.43 and $73.73 \%$ of the EU average for these three types of card. Consequently, the corresponding estimated values of the total annual transactions per card for each type of card are only 52.43, 18.03 and 68.14\% of the EU average. (See details in Table 2. Data for cash holdings as of 2001.)
} 
reward and loyalty bonuses. ${ }^{19}$ The Visa International decision seemingly agrees, when acknowledging the "advantages to the system of encouraging consumers to become cardholders... [in] geographic markets where the take up of cards has not reached saturation point” (para. 71, footnote 37). Even such a strong critic of MIFs as Alan Frankel also seems to concur. ${ }^{20}$

Furthermore, recent changes in Spain confirm the argument, as political and regulatory pressure since 1999 has coincided with a slowdown in the development of the market. On May 12, 1999, as the result of a commission promoted and chaired by the Government, the three payment networks agreed with the main merchants' associations to reduce maximum MIFs to 2.75\% in July 2002. ${ }^{21}$ The networks have also been subject to Parliamentary nonlegislative proposals and investigations by the national competition authority. Since then, MIFs have been reduced substantially, annual fees have increased and growth in the supply of terminals and cards has been damaged. Thus, between 1999 and 2003, the number of POS terminals accepting payment cards increased only $32.85 \%$ in Spain, well below the average increase of $49.65 \%$ in the EU (see Table 2). ${ }^{22}$ The issuance of new cards has also slowed down, especially in 2003.23

\subsection{To the extent that cardholders' fees do not offset the reduction in MIFs, issuers will be underpaid. This may lead to undesirable transformations in the Spanish payment networks}

To the extent that issuers can not offset the fall in MIFs by charging higher fees to cardholders, two types of consequences will follow. First, as issuing banks would be unable to cover the costs of the services they provide and the compensation between acquirers and issuers would be unbalanced, there is a risk that networks could unravel. ${ }^{24} \mathrm{~A}$ vicious circle

\footnotetext{
19 Given that it is the cardholder who decides on the use of the card, incentives at the merchant side would require merchants devising ways of motivating cardholders. This has been a common practice for card stores (giving customers free parking space when using the store card or privileges in case of returns). In any case, it would be costly, probably ineffective and, more important, out of reach for small merchants.

20 He assumes that MIFs may be necessary in immature payment card market when saying that in the U.S., a very mature market, "bank card issuers sent nearly 51ㄴ/4 billion direct mail solicitations to U.S. households in 2004 ... [but] average response rate to these solicitation offers has fallen to only $0.4 \%$.... So it would seem hard to claim that interchange fees are necessary today to overcome a chicken and egg entry barrier problem." (Alan S. Frankel, "Interchange Fees in Various Countries: Comment on Weiner and Wright," Conference on “Interchange Fees in Credit and Debit Card Industries: What Role for Public Authorities?,” Federal Reserve Bank of Kansas City, Santa Fe, New Mexico, May 4-6, 2005, p. 9, emphasis added).

21 This agreement was notified to the TDC and individually exempted by virtue of Decision of April 26, 2000, No. A 264/99, Tasas Pago con Tarjeta.
}

22 Data from the European Central Bank (2005, op. cit., n. 18). The central bank of Spain observes "in the last years a slight slowdown in the growth rate of the number of ATMs and POS terminals, being even possible to speak of stagnation for some quarterly observations.” (Bank of Spain, op. cit., 2005, n. 17, p. 63).

23 Bank of Spain, op. cit., 2005, n. 17, p. 62.

24 The unbalanced compensation between acquirers and issuers was partly responsible for the slow development of the market, as it was felt in Spain during the first years of the payment card market. Before the networks had been able to fine tune their prices, the activity of acquiring merchants was rewarded better than that of issuing cards and, as a consequence, banks installed too many POS terminals and issued to few cards. Some time later, the price structure was changed in the opposite direction, resulting for a short while in the opposite imbalance in incentives and behaviors, before the current pricing structure was finally introduced, a structure that seems to have been motivating a balanced mix of both acquiring and issuing activities. 
might develop and the whole system could collapse, with the four-party networks fragmenting in three-party networks headed by big banks, four-party networks being scaleddown and small banks being forced to operate through bilateral agreements. ${ }^{25}$ These bilateral arrangements would entail higher costs for small banks, potentially driving some of them out of business, to the detriment of competition.

Large banks would have an incentive to withdraw from four-party networks and create their own three-party networks in which acquirers will only serve the issuing bank's clients. They would also have the means: domestic branch networks, broad customer bases of merchants and cardholders, detailed databases and knowledge of merchants and cardholders. In pursuing that strategy, they would internalize the positive externalities they produce in issuing cards by pricing correctly to merchants and cardholders.

This would damage medium-sized and small banks, which will be unable to provide a similar service, as emphasized by the Visa International decision (para. 59). In particular, small banks would strive to reach bilateral agreements, but their negotiation and management would be surely very costly, leading to higher discount fees, as predicted by the Visa International decision (para. 101). ${ }^{26}$ Furthermore, the qualification foreseen in this prediction of the Visa International decision for those domestic markets with few participants is not applicable to Spain, ${ }^{27}$ because the three networks active in the market have as much as 168 members. ${ }^{28}$ Therefore, transactions costs of bilateral contracting would be very high.

This dismal scenario is likely if the TDC decisions are applied in full. However, even if the rules set out by the TDC are toned down, they will cause substantial damage to the development of the immature Spanish market.

A second possibility arising from the decisions would be a substantial unbundling and underprovision of services. To the extent that issuers are not allowed to recover the cost of specific services through merchants and that direct recovery from users is not realistic, issuers will stop providing such services, which will then be unbundled and, given the difficulties associated to their provision by third parties, those services will also be underprovided or provided at higher cost. This will happen with the payment guarantee and the free funding, if the TDC decisions are implemented, given that these costs would be excluded from the standard package of services, and should be provided either for a separate price (if this were economically and legally viable), or not provided at all. Transaction services will also suffer the consequences of the exclusion by the TDC of the possibility of pricing them in variable terms. Let us now examine this process for each of these three cost elements.

\footnotetext{
25 A recent article in the most influential Spanish business weekly asserted that "change in the rules of the game [on MIFs] could alter the whole system of electronic payments in Spain and incline banks and savings and loans associations to migrate towards alternative payment systems" ("Los tribunales también 'pasan' la tarjeta," Actualidad Económica, September 15, 2005, p. 48).

26 The Commission concludes that "due to negotiation and transaction costs bilateral interchange fees though theoretically possible, would result in higher and less transparent fees. This is in its turn likely to lead to higher merchant fees” (Commission Decision as COMP.29.373, VISA International, OJ L 318, 22.11.2002, para. 101, p. 34).

27 “This conclusion [on the efficiency gains of a multilateral interchange fee due to lower negotiation and transaction costs in the context of the Visa international payment scheme] is not necessarily valid in a domestic context, where the number of banks may well be far fewer and the efficiency gains of a multilateral arrangement vis-à-vis bilateral agreements may not outweigh the disadvantage of the creation of a restriction of competition” (Commission Decision as COMP.29.373, VISA International, OJ L 318, 22.11.2002, n. 45, p. 34).

28 Euro 6000 has 35 members; 4B, 31; and Servired, 102 (Bank of Spain, op. cit., 2005, n. 17, p. 59, footnote 5).
} 


\section{Consequences of excluding most costs in the payment guarantee}

\subsection{Consequences of the fact that banks do not continue guaranteeing payments in domestic transactions given the high cost and value of this guarantee in Spain}

If Spanish banks stop guaranteeing payment in domestic card transactions, both cardholders and merchants would be damaged because both of them value such guarantee against credit risk and would not find effective substitutes.

The guarantee is valuable in all countries because it is a requirement for the acceptance of cards. Indeed, without a payment guarantee, large merchants would extend or develop their own systems, but many medium-sized and small merchants would cease to accept cards, as recognized by the Visa International decision, which considers the suppression of this cost as a factor which is likely to cause "a downward spiral in the size and level of usage of the Visa system, and a loss in turnover for all merchants” (para. 88).

But the payment guarantee is especially valuable in Spain due to the low effectiveness and high costs associated to the recovery of debts through judicial procedures and the important demand for consumer credit. Indeed, collecting debts in Spain is particularly difficult despite recent legal reforms. According to the World Bank, Spain is the OECD country with the most complex judicial procedures for debt collection (index 82.6 compared to an EU15 average of 55.0), complexity that makes debt collection very costly. For a standard case, costs are as high as $10.7 \%$ of gross national individual income versus an EU average of 5.9\% (Table 3). ${ }^{29}$ It has been estimated that only half of all debts are paid without delay and 3.2\% are never paid. ${ }^{30}$ In particular, the effective legal position of bills and checks is weak and they are, therefore, hard to collect: as much as $3.6 \%$ of commercial bills end up unpaid, according to the National Statistical Institute. Understandably, checks are not used for over the counter purchases, with only bank-guaranteed checks being used among anonymous parties. However, guaranteed checks do not only cost about $1.5-2 \%$ of its amount to the client, but merchants have to pay an additional $2 \%$ to collect them. Discount and collection of commercial bills is even costlier, ranging from 0.5 to $5 \%$, with fixed fees, minimum fees and add-ons. Invoice collection may cost as much as $12 \%$ of face value with a minimum of $45 €$. $^{31}$

As it can be deduced from this background, granting of credit entails high transaction costs. Nevertheless, the demand for consumer credit is huge: a recent survey indicates that $96 \%$ of Spaniards consider that, when merchants offer to finance consumer purchases, this offer gives them "a very important advantage;" and 88\% agree that without financing

\footnotetext{
29 World Bank, Doing Business in 2005: Removing Obstacles to Growth, Oxford University Press, Washington DC, 2005.

30 Clara Fraile, “Cobro de morosos: Entre tres y cuatro de cada cien facturas emitidas se quedan sin pagar,” Consumer, May, 2004, reporting on the basis of estimates produced by Intrum Justitia.

31 According to the official fee schedules of the two main banks, SCH and BBVA, published by the Bank of Spain (“Tarifas bancarias," http://www.bde.es/noticias/dot/tarbp.htm, accessed September 15, 2005).
} 
merchants would sell less. ${ }^{32}$ Considering both the cost and value of credit, it is obvious that the payment guarantee gives unique value to Spanish small merchants, who are unable to sell on credit by themselves.

\title{
3.2 Lack of substitutes in Spain: credit insurance and factoring are not substitutes and would amount to costs higher than the discount rates of credit cards
}

Products that replicate the payment guarantees provided by the card networks are not currently sold in Spain. Not even third party check guarantee services, which might be seen as analogous to the card network payment guarantee, are provided. The closest available analogy would be commercial credit insurance, which is provided in different forms, like factoring 33 and pure credit insurance. ${ }^{34}$ However, it only insures trade credit, not consumer credit.

The characteristics common to both factoring and credit insurance demonstrate important lessons, however. Mainly, because both of these financial services are only producible on the

\begin{abstract}
32 Millward Brown Spain, "Estudio sobre uso e imagen de la financiación en los servicios y consumo," prepared for ASNEF, February, Madrid, 2005 (http://www.asnef.com/, accessed September 15, 2005).

33 It is the so-called factoring without recourse, by which merchants sell their invoices for future payment. However, even in the more developed US market it is difficult for businesses to find a factor willing to operate with them if their monthly receivables add to less than $\$ 10,000$. And it is very expensive: factors pay upfront 70 to $90 \%$ of the face value of the debt plus another fraction and this only after the debt is collected. The final total discount is usually between 5 to $10 \%$ of face value, and varies with the payment period, the industry and the credit history of clients. Furthermore, it is unsuitable for firms with small transactions, which make it useless for many merchants currently relying on credit cards. See, for instance, Business Owner Toolkit, "Factoring," http://www.toolkit.cch.com/text/P10 3730.asp; Vilma González Morales, "Aspectos generales relacionados con el factoraje,” http://www.monografias.com/trabajos12/facto/facto.shtml; José Leyva, "El factoring, un negocio de autofinanciamiento," http://www.injef.com/php/index.php?option=content\&task=view\&id=361\&Itemid=32 (the three works accessed on September 15, 2005).
\end{abstract}

${ }^{34}$ Commercial credit insurance enjoys in Spain one of the highest penetration rate worldwide (around $0.060 \%$ of GDP), accounting for 7\% of the world market. (Swiss RE, "El seguro de crédito comercial: La globalización y el negocio electrónico presentan grandes oportunidades,” Sigma, 7, September 30, 2000,

[http://www.swissre.com/INTERNET/pwsfilpr.nsf/vwFilebyIDKEYLu/SHOR-

563HAK/\$FILE/sigma7_2000_s_rev.pdf, accessed September 15, 2005]; and J. H., "El seguro de crédito, blindaje de las empresas frente a los impagos,” $A B C$, November, 21, 2004). However, the number of insured firms is small, with estimations of around 34,000. Policies sold by Crédito y Caución (CyC), who enjoys a 60\% market share, are much worst than those bundled with credit cards, in terms of exclusions, complexity and coverage: $\mathrm{CyC}$ policies exclude sales to individuals, transactions below a minimum figure and sales exceeding the credit limit authorized by the insurer for each one of the insured's clients. Its procedures are complex because before making an offer the insurer analyzes the insured's sector, turnover and credit terms, as well as the geographic distribution of its clients. Moreover, to eventually collect an indemnity, insured firms have to obtain a credit limit for each of their clients; monthly notify their total turnover; and pay the premiums, which are calculated as a variable proportion of sales. Creditors also have to exhaust friendly collection procedures, and after these fail, send the insurer a "claims notice" and the original documentation for the unpaid credit. Only at that point a loss occurs and an indemnity is paid. But this indemnity is only a percentage of the insured loss and, therefore, provides incomplete coverage. (See

http://www.creditoycaucion.es/ingles/productos/seguro_credito.asp, accessed September 15, 2005). All these exclusions and limitations probably remove much of the adverse selection and moral hazard potentially plaguing the industry. However, the average premium of credit insurance still reaches averages as high as 0.20 to $0.25 \%$ of sales (Patricia Pérez Zaragoza, "Las empresas se blindan con seguros de crédito," El Comercio, January 9, 2005). It is therefore likely that a policy with the inclusiveness, full coverage and automatism of the insurance being now bundled with credit cards would cost many times that amount. 
basis of previous screening of borrowers, using databases compiled or produced by insurers who examine carefully both potential insured clients and borrowers.

No insurer can reasonably be expected to be able to assess the creditworthiness of each individual consumer who might wish to use a card to make a purchase. Consultation with more than a few London syndicates has confirmed this point, as none of them has been willing (or see themselves in a position able) to underwrite consumer credit in Spain or in any other European country.

If one were to imagine how third party providers might arrange credit insurance for consumers, they would undoubtedly need to rely on extensive databases, which would hold updated data on consumers' solvency. ${ }^{35}$ Building and keeping these databases, however, enjoy obvious synergies with conventional banking activities. ${ }^{36}$ For a third party to construct and maintain such a system would be very costly, and the cost would be borne by the merchants who would be purchasing the insurance. If, alternatively, these third parties providers were to purchase the information from banks, merchants would also end up paying. Moreover, this solution would incur additional substantial transaction costs, given the "specificity" of such databases, which makes them natural candidates for vertical integration. Furthermore, the situation would be bizarre because, under the TDC rules on MIFs, banks could recover the costs of such databases when supplying information to third parties but would not be allowed to recover such costs in their own credit card transactions.

In addition, any third party insurance would not provide universal coverage, to both all cardholders and to all merchants, as the card networks do today. Not all debtor firms are considered creditworthy by commercial credit insurers, and they must be expected to operate under similar basis for individuals. Similarly, smaller merchants and merchants engaged in riskier types of business might be unable to find coverage at all, as it happens now in commercial credit insurance. Furthermore, those who are eligible for coverage would be charged a premium (including a minimum premium) and would be subject to a deductible as well as a cap. And, of course, the insurer would need to make a profit on this insurance. There is no question that the ultimate cost would be higher for the vast majority of merchants than it is today, and the scope of coverage would be inferior.

\subsection{The cost and nature of the payment guarantee}

These databases and other default-prevention resources have crucial and often negative consequences in terms of costs' structure.

Indeed, credit card lending is one of the most risky activities for banks. For example, the Bank of Spain computes credit card loans within the riskiest categories of bank assets, together with consumer financing and overdrafts. ${ }^{37}$ The Bank of Spain estimates that the doubtful assets ratio was $1.5 \%$ for 1999 and 4\% for 2003 of the total card credit

\footnotetext{
35 See in this regard, Margaret E. Guerin-Calvert and Janusz A. Ordover, "Merchant Benefits and Public Policy towards Interchange: An Economic Assessment," Conference on “Antitrust Activity in Card-Based Payment Systems: Causes and Consequences,” Federal Reserve Bank of New York, New York, September 15-16, 2005 (www.newyorkfed.org/research/conference/2005/antitrust/Guerin_Calvert_Ordover.pdf, accessed September 15, 2005).

36 See George J. Benston and Clifford W. Smith, “A Transactions Cost Approach to the Theory of Financial Intermediation,” Journal of Finance, 31(2), May, 1976, pp. 215-231.

37 Bank of Spain, Informe de Estabilidad Financiera, Madrid, May 2003, p. 23 (http://www.bde.es/informes/be/estfin/estfin.htm, accessed September 15, 2005).
} 
outstanding. ${ }^{38}$ On the basis of the previous economic cycle, most banks were recording $1.5 \%$ of their total credit card loans in 2002 (last year for which this data is available) as an allowance for doubtful accounts. ${ }^{39}$ The costs of effective defaults are therefore very substantial. However, effective defaults are not the full cost of the payment guarantee, which also includes the cost of avoiding defaults, that is, the issuing banks (or the networks in three party systems) spend more resources in preventing and avoiding the potential existence of defaults than in covering real defaults. These preventive default-avoidance measures include all those investments and activities necessary (1) to determine the economics of potential target groups; (2) to evaluate credit risk of individuals before issuing them cards (around 50\% rejection rate is common in quality cards); and, once the cards are issued, (3) to authorize specific transactions in a way that minimizes the chances of default (this requires keeping track of individual expenditure and payment records, and developing and operating credit scoring systems). ${ }^{40}$

In conclusion, lenders could not survive by merely insuring merchants on an actuarial basis-paying bad debts from what they earn from their good debts_-, but they must prevent bad debts altogether. An actuarial approach to lending would die from adverse selection and moral hazard. Adverse selection because, without previous screening, those borrowers more prone to default would be the ones borrowing the most. Moral hazard because borrowers, lacking proper incentives to pay, would default more.

The TDC makes two fundamental mistakes when arguing that the payment guarantee does not cost anything to the banks, given that banks always end up collecting their bad debts: ${ }^{41}$ first, the TDC overlooks that banks do not always recover payments, as the figures published by the Bank of Spain clearly show; second, the TDC ignores the huge costs of preventing default, which are vital for the existence of credit.

\footnotetext{
38 These estimations are based on insolvency rates for specialized credit outlets, as no separate data is publicly available for banks. See Bank of Spain, Informe de Estabilidad Financiera, Madrid, May 2005, p. 42, Graph I.5(c) (http://www.bde.es/informes/be/estfin/estfin.htm, accessed September 15, 2005). A good part of its variability may have been caused by new entrants accepting higher rates of default in its first years of business. Estimations are also based downwards, however, because given the legal difficulties to proceed against credit cards users, many banks treat these non-payments as overdrafts on the associated current accounts, and the final defaults therefore end up misclassified. Even higher default rates are common in less developed markets. For instance, a recent report estimated defaults in 6.5\% of outstanding credit in Peru, according to Superintendencia de Banca, Seguros y AFP, Noticias Diarias, May 5, 2005

(http://www.sbs.gob.pe/PortalSBS/noticias/historico/2005/Mayo/05.05.2005.htm, accessed September 15, 2005).

39 In application of the Bank of Spain’s Regulation 9/1999. See Bank of Spain, Informe de Estabilidad Financiera, Madrid, November 2002, pp. 26-27 (http://www.bde.es/informes/be/estfin/estfin.htm, accessed September 15, 2005). Rule 4/2004 (http://www.bde.es/normativa/circu/c200404.pdf), enacted in January 2005 in order to adapt the Spanish standards to those of the International Accounting Standards Board, maintains the same consideration of credit card lending as one of the most risky and the same allowance.

40 The problem is more general, affecting all industries which are dedicated to prevent risks and, as a consequence, have a hard time convincing clients and regulators about the reasonableness of their prices. What happens is that clients and regulators do easily perceive and recognize the costs of paying the losses that these firms suffer (defaults in the case of credit insurance). However, both clients and regulators are prone to miss, and are therefore reluctant to recognize, the less explicit but often greater costs incurred in preventing losses. See on this, Benito Arruñada, “A Transaction Cost View of Title Insurance and its Role in Different Legal Systems,” The Geneva Papers on Risk and Insurance, 27(4), October, 2002, pp. 582-601.

41 TDC Decision of April 11, 2005, No. A 314/02, Tasas Intercambio SISTEMA 4B, p. 35.
} 


\subsection{Conclusion: The criteria in the Visa International decision are fully applicable to domestic transactions but they were not applied by the TDC, who only allows payment systems to include fraud in their MIFs}

The two arguments used by the Visa International decision for including the payment guarantee are fully applicable in light of the circumstances of Spanish domestic transactions. The Commission considered that merchants benefit from this "insurance" and, in its absence, they would have to self-insure. Moreover, it found no evidence of third party provision of this service, (which would in any case be inefficient) (see paras. 86 to 88). All these elements are present in Spanish domestic transactions.

The Visa International decision also argued that the payment guarantee is more costly for cross-border transactions because of more difficult recovery. However, recovery in domestic transactions is a matter of the particular performance of institutions in each country. In the case of Spain, recovery is particularly costly and inefficient. Therefore, the reasoning of the Commission in relation to this cost in the Visa International decision is fully applicable to Spanish domestic interchange fees.

\section{Consequences of excluding the cost of the free funding period}

\subsection{Consequences of banks ceasing to provide a free funding period}

If banks have to stop providing the free funding period to cardholders, cardholders will have to dedicate more recourses to manage their cash, to avoid the cost of overdrafts, as high as $4.5 \%$ with a minimum between 3 and $15 € .42$ To the extent that buyers cannot easily check the balance in their current accounts, they will spend more in searching costs and will often postpone and concentrate their purchases.

Free funding not only allows buyers to anticipate their demand, it also smoothes consumption. This smoothing greatly benefits merchants by reducing their optimal capacity and therefore their cost of capital: As clients purchase more regularly, stores are smaller and fixed resources are better utilized.

This makes clear that the value of free funding and the losses from its disappearance are different for large and small merchants. Large merchants will benefit from the greater demand enjoyed by their integrated payment systems, based on store cards, which will continue offering free funding as they have always done, but now as sole providers of such service. Small merchants, however, will suffer, because they will find impossible to provide a similar service.

\subsection{Greater benefits of free funding in Spain}

Free funding is especially valuable for those people who are less methodical in their cash management. It is therefore especially valuable in Spain, because of the prevalence of last minute improvisation, of which there is ample evidence for both consumers and merchants.

42 Same source as that in n. 31. 
Surveys repeatedly point out that most Spaniards have financial difficulties to make ends meet and "reach the end of the month," 43 the moment when salaries are typically paid and even city traffic becomes much less fluid. Similarly, Spanish firms are quite lenient in their cash management, as pointed out by the preparatory works of the Directive on late payments (see Table 4). ${ }^{44}$ Spanish merchants are therefore likely to benefit greatly from the cash management and reliable payment services provided through the card payment networks.

\subsection{Conclusion: the arguments used by the Visa International decision to include the cost of the free funding period do hold for Spanish domestic transactions}

The TDC view is that the Visa International decision includes the cost of the free funding period due to its special value in cross-border transactions, and that this special value does not apply to domestic transactions. This interpretation is mistaken, because cardholders suffer similar difficulties for checking their bank balances in domestic as well as in cross-border transactions.

The Commission ponders that international travelers have difficulties to know the balance in their bank account when they are traveling. However, most cardholders suffer the same problem when they are in a store and do not know their balance. This is especially true for travelers in domestic markets, who, not knowing a city well enough, face serious difficulties to find an ATM machine or a bank office where they can check their account. Their cash management is made much easier by having a line of credit in their cards, which acts as cushion and can be controlled once a month. Otherwise, significant purchases would be postponed until the balance is checked and, as a result, many intended purchases would not be made.

\section{Consequences of excluding many processing costs and establishing a flat fee}

The TDC decisions exclude many processing costs and deny that other processing costs vary with the value and type of the transaction. Consequently, the resulting MIFs would not allow to recover some processing costs and would misallocate other costs among transactions and industries.

\footnotetext{
43 In the first quarter of 2005, 54.74\% of Spanish families found it difficult to make ends meet according to a survey of the National Statistical Institute that they INE, “Encuesta de Presupuestos Familiares,” Quarterly survey, Madrid, 2005).

44 For instance, the data collected by Intrum Justitia showed that the average payment period of Spanish firms was 68 days, compared to an EU average of 39 days, only behind the 75 days of Greek firms. See, for data, European Payment Habits Survey, Intrum Justitia, Amsterdam, April 8, 1997; and, for an analysis, Benito Arruñada, La Directiva sobre morosidad, Marcial Pons-Instituto de Estudios de Libre Comercio, Madrid, 1999. The situation is getting worse: in a 2003 update of the said data, the payment period was 67 days but average delay increased to 13.4 days.
} 


\subsection{Consequences of excluding processing costs}

The TDC excludes the costs of administering cards, such as those of keeping files for managing risk and keeping the card's account, as well as those of solving disputes, with the argument that they do not "fundamentally" benefit merchants.

This benefit-to-merchants criterion is misleading and the analysis ends up being flawed unless proper consideration is given to indirect benefits, that is, externalities, which have been recognized by the Visa International decision. ${ }^{45}$ Otherwise, when benefits are narrowly seen as direct, immediate and observable benefits, as done by the TDC, less visible benefits remain unrewarded and will, therefore, be underprovided. 46

The consequences of this underpricing may be minor for cross-border transactions (because most investments are decided on the basis of national markets), but they are crucial for national MIFs. If issuers are forced to recover their investments only from cardholders, and cardholders are not rewarded for the externalities they produce, underinvestment is inevitable and will only be made worse by the usual lag in observability until investments need to be renewed.

\subsection{Consequences of forbidding variable and sectorial pricing}

The TDC accepts including in the calculation of MIFs the costs of authorizing, clearing and settling transactions, because they "benefit merchants" 47 by allowing them to transact with unknown clients belonging to banks other than their acquiring bank. The TDC argues, however, that these costs are the same for all transactions, whatever their value, and in all sectors. Consequently, the TDC only allows to include in the MIF a fixed processing cost, constant with value and across merchant industries.

The basis for this rationale is factually wrong, as the processing costs of authorizing, clearing and settling are not the same across different transactions and industries. Service and quality control cannot be the same for small and large amount transactions, as clearly shown by the common practice of processing small transactions in batches and even without authorization. In addition, most interchange fees in the Spanish financial markets have a mixed structure, with fixed and variable components. ${ }^{48}$ These interchange rates provide a suitable comparison, because they respond to a similar technology (network economies, multiparty markets, types of risk) and institutions (law, judiciary, regulators, education).

The rationale for sectorial differences is also discernible in the distribution of fees across industries. As shown in Table 5 below, higher fees are charged in sectors in which the card network provides more services, mainly suffering higher default and fraud rates, which are partly driven by the lower transaction costs of second hand transactions. For example, MIFs for car rental are higher than in other sectors, because they include a greater element of risk:

\footnotetext{
45 "The Commission does accept that a four-party payment scheme is characterized by externalities, and that there is interdependent demand from merchants and cardholders” (para. 65).

46 The evaluation of benefits should in any case be deduced from behavior. Considering the high price of alternative services, it is hard to believe that merchants accept cards purely because of strategic reasons, and not on the basis of the value they get from the services being provided.

47 Not without considering, however, that part of these costs might be paid by cardholders.

48 See Instituto Superior de Técnicas y Prácticas Bancarias, Práctica, normalización y regulación del sistema y los medios de pago, Madrid, 2005.
} 
in addition to the rental price, the user is committed to future payments, such as those caused by collision or damage when total or partially uninsured, traffic tickets, late delivery and gas and service charges. These events may lead to disputes between the cardholder and the issuer, where the latter needs to cover the costs of the subsequent investigations made also for the benefit of merchants. In general, top rates are applied in sectors with higher default and fraud rates, the latter because the transaction costs of selling second hand goods are either low (jewelry) or zero (casinos), as well as for personal services (saunas, hotels) for which not even a second transaction is needed to obtain a benefit from fraudulently using a card.

Consequently, the application of the TDC rules would cause serious redistribution and misallocation of resources, with high-cost transactions and industries subsidizing those with low costs. ${ }^{49}$ Moreover, to the extent that wealthier cardholders are those making bigger and costlier transactions, the TDC scheme of fixed pricing-irrespective of transaction size and therefore transaction cost-would redistribute wealth from poor to wealthy cardholders. Similarly, department stores and hypermarkets would profit doubly from their greater possibilities of aggregating small transactions, to the detriment of specialized merchants. Large retailers appear, again, as the only winners in this regulatory venture, whereas consumers, unfortunately, are likely to be the main losers.

\section{Conclusion}

In summary, this paper concludes that the TDC decisions interpret too narrowly the Visa International decision and exclude from the MIF certain costs which provide important benefits to the participants in the Spanish card market. Artificially lowering the MIFs will not necessarily lower consumer prices and will lead to higher cardholders' fees. By prohibiting the inclusion of the cost of certain significant and valuable services in the MIF, the TDC decisions have removed essential benefits to merchants and consumers, and eliminated incentives in a market (Spain) that needs development and growth. This may result in potential imbalances between participants, threatening to cause detrimental impact to the networks.

Moreover, making it uneconomic for the networks to provide fundamental services (guarantee of payment beyond fraud cost and free funding period) will lead to the unbundling of those services under the MIF, thereby causing the participants to obtain them separately (if at all) at substantial hardship and increased costs. It is questionable in the Spanish market whether certain services like the payment guarantee for credit risk and interest free funding can be replaced; and, even if the interest free funding could be replaced, it would be at a far greater cost. In addition, fixing processing costs at an unrealistically low level further creates serious financial strain on the system, and will lead to an inefficient and ineffective allocation of such interchange costs among transactions and industries.

The emerging Spanish card market needs a broader base of participants to stimulate its development if it is to become robust and vibrant. Instead, the consequences of the TDC decisions will negatively impact and stifle the growth of this market.

\footnotetext{
49 A reduction in the range of MIFs across sectors has already been observed in Spain after the 1999 agreement mentioned in n. 21. Maximum discount rates fell from $3.48 \%$ to $2.98 \%$ but minimum rates increased from 0.54\% to 0.70\%, between 2002 and 2004 (Bank of Spain, op. cit., 2005, n. 17, p. 59).
} 


\section{Appendix}

Table 1. Market shares of store/label cards in the European Union (1998-1999)

\begin{tabular}{lccc}
\hline & $\begin{array}{c}\text { Number of cards in } \\
\text { circulation-POS } \\
\text { capability }\end{array}$ & $\begin{array}{c}\text { Total number } \\
\text { of card transactions } \\
\text { at POS }\end{array}$ & $\begin{array}{c}\text { Total value } \\
\text { of card transactions } \\
\text { at POS }\end{array}$ \\
\hline France & $45.95 \%$ & $10.95 \%$ & $12.20 \%$ \\
Sweden & $32.87 \%$ & $19.69 \%$ & $13.04 \%$ \\
Spain & $19.54 \%$ & $8.55 \%$ & $10.03 \%$ \\
Finland & $18.66 \%$ & $9.44 \%$ & $11.28 \%$ \\
Denmark & $18.25 \%$ & $0.24 \%$ & $1.44 \%$ \\
United Kingdom & $14.85 \%$ & $1.75 \%$ & $1.29 \%$ \\
EU average & $12.72 \%$ & $4.77 \%$ & $5.73 \%$ \\
Belgium & $10.79 \%$ & $14.60 \%$ & $26.75 \%$ \\
Italy & $9.01 \%$ & $0.72 \%$ & $0.95 \%$ \\
Austria & $6.32 \%$ & $0.51 \%$ & $2.26 \%$ \\
Portugal & $4.73 \%$ & $0.60 \%$ & $1.03 \%$ \\
Netherlands & $3.45 \%$ & $0.33 \%$ & $1.17 \%$ \\
Germany & $3.41 \%$ & $4.13 \%$ & $4.48 \%$ \\
Greece & $2.15 \%$ & $0.06 \%$ & $0.08 \%$ \\
Ireland & $0.81 \%$ & $0.00 \%$ & $0.00 \%$ \\
Luxembourg & $0.00 \%$ & $0.00 \%$ & $0.00 \%$ \\
\hline
\end{tabular}

Note: These data substantially underestimate the true number because it uses 1998 data store cards and 1999 data for the rest. Source: Commission Decision as COMP.29.373, VISA International, OJ L 293, 11.10.2001, pp. 39-41. 
Table 2. Comparison of the Spanish and European payment systems in 2003

\begin{tabular}{|c|c|c|c|}
\hline & Spain & $E U$ & Spain/EU \\
\hline \multicolumn{4}{|l|}{$\begin{array}{l}\text { Banknotes and coins in circulation outside credit institutions (end of } \\
\text { 2001): }\end{array}$} \\
\hline Value per inhabitant $(€)$ & 1,060 & 815 & $130.06 \%$ \\
\hline As a percentage of GDP & 6.5 & 3.5 & $185.71 \%$ \\
\hline \multicolumn{4}{|l|}{ Cards with a cash function and ATMs: } \\
\hline Number of ATMs per 1,000,000 inhabitants (end of year) & 1,274 & 732 & $174.04 \%$ \\
\hline Number of transactions per inhabitant & 22.0 & 28.0 & $78.57 \%$ \\
\hline Average value per transaction $(€)$ & 97.0 & 122.0 & $79.51 \%$ \\
\hline Estimated total value of transactions per inhabitant $(€)$ & 2,134 & 3,416 & $62.47 \%$ \\
\hline Estimated number of transactions per ATM & 17,268 & 38,251 & $45.14 \%$ \\
\hline Estimated total value of transactions per ATM $(€)$ & $1,675,039$ & $4,666,667$ & $35.89 \%$ \\
\hline \multicolumn{4}{|l|}{ Cards with a debit function and POS terminals: } \\
\hline Number of POS terminals per 1,000,000 inhabitants (end of year) & 23,514 & 13,678 & $171.91 \%$ \\
\hline Number of transactions per inhabitant & 15.5 & 38.8 & $39.95 \%$ \\
\hline Average value per transaction $(€)$ & 43.6 & 60.2 & $72.43 \%$ \\
\hline Estimated total value of transactions per inhabitant $(€)$ & 676 & 2,336 & $28.93 \%$ \\
\hline Estimated number of transactions per POS terminal & 659 & 2,837 & $23.24 \%$ \\
\hline Estimated total value of transactions per POS terminal $(€)$ & 28,740 & 170,768 & $16.83 \%$ \\
\hline \multicolumn{4}{|l|}{ Cards with a credit function and accepting terminals: } \\
\hline $\begin{array}{l}\text { Number of accepting terminals per 1,000,000 inhabitants (end of } \\
\text { year) }\end{array}$ & 23,514 & 13,998 & $167.98 \%$ \\
\hline $\begin{array}{l}\text { Increase in the number of accepting terminals (\% increase between } \\
1999 \text { and 2003) }\end{array}$ & $32.85 \%$ & $49.65 \%$ & $66.17 \%$ \\
\hline Number of transactions per inhabitant & 11.4 & 13.4 & $85.07 \%$ \\
\hline Average value per transaction $(€)$ & 61.2 & 83.0 & $73.73 \%$ \\
\hline Estimated total value of transactions per inhabitant $(€)$ & 697.7 & $1,112.2$ & $62.73 \%$ \\
\hline Estimated number of transactions per POS terminal & 485 & 957 & $50.65 \%$ \\
\hline Estimated total value of transactions per POS terminal $(€)$ & 29,671 & 79,454 & $37.34 \%$ \\
\hline \multicolumn{4}{|l|}{ Utilization of cards, average number of: } \\
\hline Cash withdrawals per card with a cash function & 15.3 & 23.2 & $65.95 \%$ \\
\hline Payments per card with a debit function & 11.1 & 44.6 & $24.89 \%$ \\
\hline Payments per card with a credit function & 19.5 & 21.1 & $92.42 \%$ \\
\hline \multicolumn{4}{|l|}{ Utilization of cards, average value of total annual transactions per card: } \\
\hline Cash withdrawals per card with a cash function & 1,484 & 2,830 & $52.43 \%$ \\
\hline Payments per card with a debit function & 484 & 2,685 & $18.03 \%$ \\
\hline Payments per card with a credit function & 1,193 & 1,751 & $68.14 \%$ \\
\hline
\end{tabular}

Source of data: European Central Bank, Payment and Securities Settlement Systems in the European Union (Addendum Incorporating 2003 Figures), Frankfurt, August 2005 (http://www.bde.es/sispago/bbestade.pdf, accessed September 15, 2005). 
Table 3. Costs and complexity of debt collection in OECD countries

\begin{tabular}{|c|c|c|c|c|}
\hline & $\begin{array}{l}\text { Number of } \\
\text { Procedures }\end{array}$ & $\begin{array}{c}\text { Duration } \\
\text { (days) }\end{array}$ & $\begin{array}{c}\text { Cost } \\
\text { (\% of Gross } \\
\text { National } \\
\text { Income per } \\
\text { capita) }\end{array}$ & $\begin{array}{l}\text { Procedural } \\
\text { Complexity } \\
\text { Index }\end{array}$ \\
\hline Spain & 20 & 147 & 10.7 & 82.6 \\
\hline France & 21 & 210 & 3.8 & 79.2 \\
\hline Poland & 18 & 1,000 & 11.2 & 65.3 \\
\hline Slovenia & 22 & 1,003 & 3.6 & 65.3 \\
\hline Czech Republic & 16 & 270 & 18.5 & 64.6 \\
\hline Italy & 16 & 645 & 3.9 & 64.3 \\
\hline Greece & 15 & 315 & 8.2 & 63.9 \\
\hline Mexico & 47 & 325 & 10 & 61.8 \\
\hline Germany & 22 & 154 & 6 & 61.1 \\
\hline Lithuania & 17 & 74 & 13 & 58.3 \\
\hline World average & 25.0 & 307.0 & 38.3 & 57.7 \\
\hline Hungary & 17 & 365 & 5.4 & 56.9 \\
\hline EU (25) average & 18.8 & 326.0 & 7.4 & 56.0 \\
\hline Latvia & 19 & 189 & 7.5 & 55.6 \\
\hline EU (15) average & 18.5 & 251.9 & 5.9 & 55.0 \\
\hline Portugal & 22 & 420 & 4.9 & 54.2 \\
\hline Austria & 20 & 434 & 1 & 53.9 \\
\hline Belgium & 22 & 365 & 9.1 & 53.5 \\
\hline OCDE average & 18.9 & 272.0 & 7.9 & 50.5 \\
\hline Korea, Rep. & 23 & 75 & 4.5 & 50 \\
\hline Finland & 19 & 240 & 15.8 & 47.9 \\
\hline Norway & 12 & 87 & 10.4 & 47.9 \\
\hline Netherlands & 21 & 39 & 0.5 & 45.8 \\
\hline United States & 17 & 365 & 0.4 & 45.8 \\
\hline Sweden & 19 & 190 & 7.6 & 44.4 \\
\hline Switzerland & 14 & 224 & 3.9 & 44.4 \\
\hline Ireland & 16 & 183 & 7.2 & 42.4 \\
\hline Slovak Republic & 26 & 420 & 13.3 & 40.3 \\
\hline Denmark & 14 & 83 & 3.8 & 40.3 \\
\hline Japan & 16 & 60 & 6.4 & 39.2 \\
\hline Turkey & 18 & 105 & 5.4 & 38.2 \\
\hline United Kingdom & 12 & 101 & 0.5 & 36.2 \\
\hline New Zealand & 19 & 50 & 11.6 & 31.3 \\
\hline Canada & 17 & 425 & 28 & 29.2 \\
\hline Australia & 11 & 320 & 8 & 29.2 \\
\hline
\end{tabular}

Note: EU 15 excludes Luxemburg, EU 25 excludes Estonia Cyprus and Malta, and OECD excludes Luxemburg and Iceland. Source: World Bank, Doing Business in 2005: Removing Obstacles to Growth, Oxford University Press, Washington DC, 2005. 
Table 4. Payment periods and payment delays in Europe in 1996

\begin{tabular}{lcccccc}
\hline & \multicolumn{2}{c}{$\begin{array}{c}\text { Contractual payment } \\
\text { period (days) }\end{array}$} & \multicolumn{2}{c}{$\begin{array}{c}\text { Payment delay } \\
\text { (days) }\end{array}$} & \multicolumn{2}{c}{$\begin{array}{c}\text { Total payment } \\
\text { period (days) }\end{array}$} \\
\cline { 2 - 7 } & $\begin{array}{c}\text { Domestic } \\
\text { market }\end{array}$ & $\begin{array}{c}\text { EU export } \\
\text { market }\end{array}$ & $\begin{array}{c}\text { Domestic } \\
\text { market }\end{array}$ & $\begin{array}{c}\text { EU export } \\
\text { market }\end{array}$ & $\begin{array}{c}\text { Domestic } \\
\text { market }\end{array}$ & $\begin{array}{c}\text { EU export } \\
\text { market }\end{array}$ \\
\hline Greece & 75 & 65 & 19 & 34 & 94 & 99 \\
Spain & 68 & 68 & 6 & 4 & 74 & 72 \\
Italy & 65 & 47 & 22 & 10 & 87 & 57 \\
Portugal & 50 & 67 & 41 & 2 & 91 & 69 \\
France & 48 & 45 & 10 & 6 & 58 & 51 \\
Belgium & 41 & 44 & 20 & 17 & 61 & 61 \\
Ireland & 35 & 35 & 16 & 14 & 51 & 49 \\
UK & 31 & 38 & 18 & 10 & 49 & 48 \\
Austria & 29 & 33 & 8 & 6 & 37 & 39 \\
Switzerland & 28 & 42 & 10 & 13 & 38 & 55 \\
Denmark & 27 & 31 & 7 & 10 & 34 & 41 \\
Netherlands & 27 & 35 & 19 & 13 & 46 & 48 \\
Sweden & 25 & 32 & 7 & 9 & 32 & 41 \\
Germany & 23 & 30 & 11 & 12 & 34 & 42 \\
Norway & 21 & 32 & 6 & 4 & 27 & 36 \\
Finland & 19 & 29 & 10 & 21 & 29 & 50 \\
\hline Average & 39 & 42 & 15 & 12 & 54 & 54 \\
\hline
\end{tabular}

Source: Intrum Justitia, European Payment Habits Survey, Amsterdam, April 8, 1997. 
Table 5. MIFs in different sectors of the Spanish economy in the fourth quarter of 2004

\begin{tabular}{lc}
\hline Sector & Fee (\%) \\
\hline Massages & 2.98 \\
Mail and phone sales & 2.51 \\
Restaurants & 2.40 \\
Casinos & 2.32 \\
Jewelries & 2.29 \\
Retailers & 2.15 \\
Drugstores & 2.14 \\
Rest & 1.95 \\
Transportation & 1.82 \\
Highways & 1.81 \\
Hotels & 1.75 \\
Shows & 1.70 \\
Car rental & 1.67 \\
Travel agencies & 1.61 \\
Pharmacists & 1.49 \\
Department stores, rest & 1.33 \\
Supermarkets & 1.23 \\
Gas stations & 0.71 \\
Department stores, food & 0.70 \\
\hline
\end{tabular}

Source: Bank of Spain, "Evolución en España de las tarjetas como medio de pago (1996-2004),” Estabilidad financiera, no. 8, May, 2005, p. 61. 